\title{
Recurrent respiratory papillomatosis with pulmonary involvement
}

\author{
Papilomatose respiratória recorrente \\ com envolvimento pulmonar
}

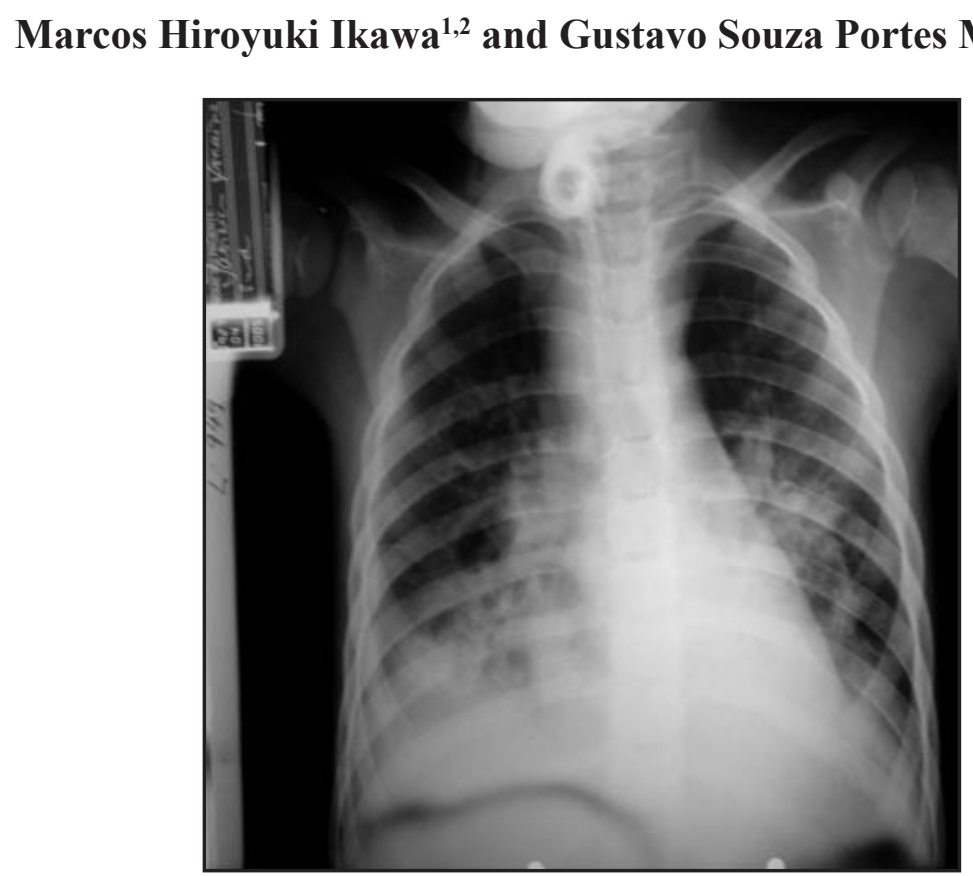

A

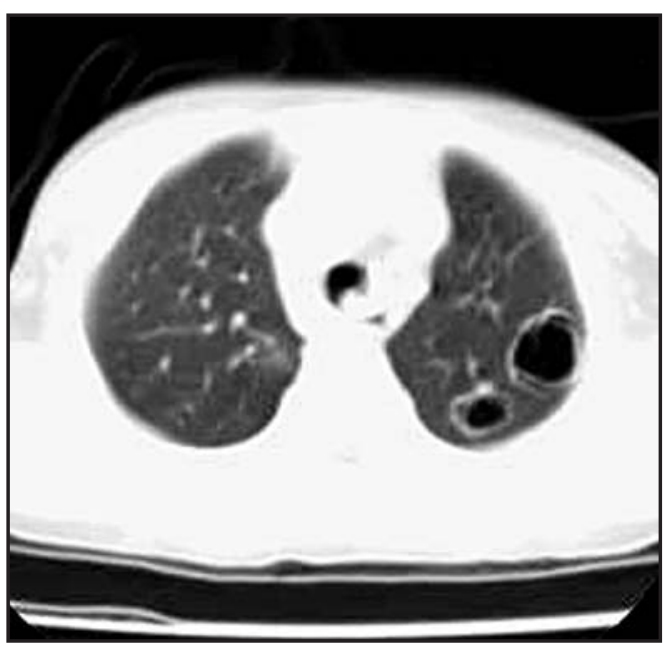

B

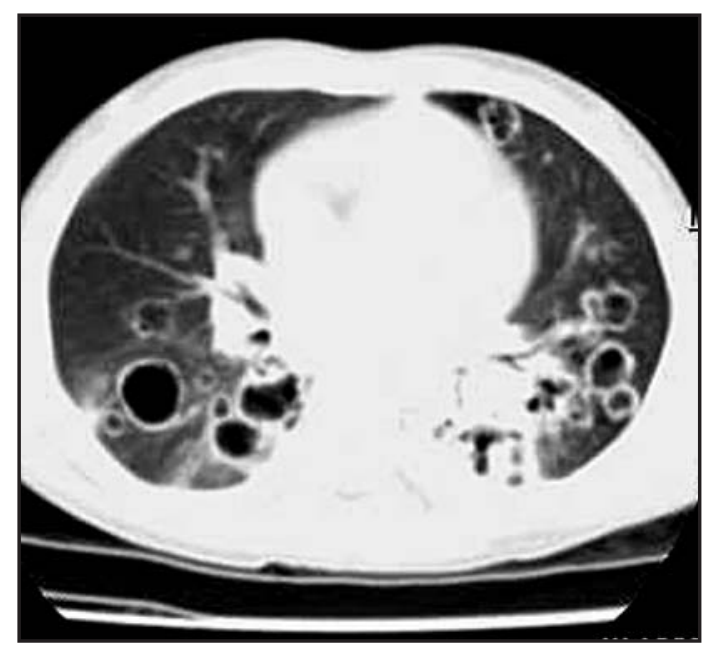

C

1. Departamento de Diagnóstico por Imagem, Escola Paulista de Medicina, Universidade Federal de São Paulo, São Paulo, SP. 2. Centro de Medicina Diagnóstica Fleury, São Paulo, SP.

Address to: Dr. Gustavo de Souza Portes Meirelles. Alameda Itu 78/1404, 01421-000 São Paulo, SP.

e-mail: gmeirelles@gmail.com

Recebido para publicação em: 16/07/2007

Aceito em: 11/10/2007 
A five-year-old girl developed hoarseness with gradual worsening at the age of eight months. Three months later, she underwent bronchoscopy in which papillomas in the vocal cords, larynx and trachea were observed. Because of serious bronchospasm crises and respiratory failure, she needed several hospitalizations, definitive tracheostomy and multiple endoscopic procedures for papilloma excision. The most recent chest radiography (Figure A) and computed tomography (CT) scans (Figures B and C) showed a nodule inside the trachea and multiple pulmonary nodules, cysts and consolidations. The anatomopathological findings from curettage of the lesions revealed benign squamous-cell papillomas. Recurrent respiratory papillomatosis (RRP) is directly related to the human papillomavirus (HPV). Its spread to the lower airways is uncommon, with involvement of trachea and/or proximal bronchi in $5 \%$ of the patients, and extension to the lungs in only $1 \%$ of the cases.

Menina, de cinco anos de idade, apresentou rouquidão aos oito meses de vida e, a seguir, houve piora progressiva. Aos 11 meses, submeteu-se à broncoscopia, onde foram observados papilomas em cordas vocais, laringe e traquéia. Devido a graves crises de broncoespasmo e insuficiência respiratória, necessitou de internações, traqueostomia definitiva e procedimentos endoscópicos para exérese de papilomas. A radiografia (Figura A) e a tomografia computadorizada (TC) de tórax (Figuras B e C) atuais evidenciaram um nódulo na traquéia e múltiplos nódulos, cistos e consolidações pulmonares. 0 resultado anatomopatológico das lesões curetadas foi de papilomas benignos de células escamosas. A papilomatose respiratória recorrente (PRR) está diretamente relacionada ao papiloma vírus humano (PVH). Sua disseminação para a via aérea inferior é incomum, com envolvimento da traquéia e/ou brônquios proximais em 5\% dos pacientes, e extensão pulmonar em apenas $1 \%$ dos casos.

\section{REFERENCES}

1. Blackledge FA, Anad VK. Tracheobronchial extension of recurrent respiratory papillomatosis. Annals of Otology, Rhinology and Laryngology 109: 812-818, 2000 .

2. Kramer SS, Wehunt WD, Stocker JT, Kashima H. Pulmonary manifestations of juvenile laryngotracheal papillomatosis. American Journal of Roentgenology 144: 687-694, 1985.

3. Neto Cade A, Campos RMC, Bastos MLS. Papilomatose respiratória recorrente com disseminação pulmonar - relato de dois casos. Radiologia Brasileira 35: 117-120, 2002. 